\section{Shining a new light on pericardial fluid}

\author{
Erin A Fender (1) , ${ }^{1}$ Chad J Zack ${ }^{2}$
}

In a healthy individual, there is $15-50 \mathrm{~mL}$ of fluid between the visceral and parietal layers of the fibroelastic pericardium. The normal composition of pericardial fluid is currently ill-defined. In the USA, pericardiocentesis is performed in patients with pericardial disease approximately 1000 times per month. ${ }^{12}$ During pericardiocentesis fluid is almost uniformly sent for laboratory analysis per guideline recommendations to quantify general chemistry and cellular composition. ${ }^{3}$ To date, there is no established methodology to assess pericardial fluid composition nor are there recognised reference values for the normal constituents of pericardial fluid. Interpretation of pericardial fluid composition is commonly performed by extending the Light's criteria validated on pleural fluid analysis to pericardial fluid. ${ }^{34}$ The accuracy of this approach to establish if pericardial fluid is transudative or exudative is unknown.

Available data regarding the biochemical and cellular composition of physiological pericardial fluid are sparse. In a study of 30 consecutive patients without pericardial disease undergoing coronary artery bypass grafting or valvular replacement that underwent pericardial fluid analysis, mean fluid lactate dehydrogenase (LDH) was 2.4 times higher and mean protein was 0.6 times lower than serum levels. $\mathrm{LDH}$ and protein fluid-serum ratio values of these normal specimens would be classified as exudative per the Light's criteria. ${ }^{5}$ A more recent study performed on 50 patients undergoing cardiac surgery without pericardial disease found that mean fluid LDH levels were 1.1 times higher and total protein in pericardial fluid was 0.5 times lower than plasma levels. ${ }^{6}$ All 50 samples of normal physiological pericardial fluid would be classified by the Light's criteria as exudates. These studies appear to suggest that the composition of pericardial fluid is distinct from pleural fluid and methods for classifying pleural effusions may not apply to pericardial effusions.

In Heart, Sabrina Buoro and colleagues sought to define specific reference values

\footnotetext{
${ }^{1}$ Cardiology, Christiana Care, Newark, Delaware, USA ${ }^{2}$ Cardiology, Penn State College of Medicine, Hershey, Pennsylvania, USA
}

Correspondence to Dr Erin A Fender, Cardiology, Christiana Care, Newark, Delaware 19713, USA; erinfender@gmail.com for pericardial fluid analysis. ${ }^{7}$ This study examined a final sample of 120 adult subjects undergoing elective openheart surgery. The study population was predominantly male (68.1\%) with a median age of 67 years and included those that underwent surgical revascularisation, valve repair/replacement, myomectomy and ascending aortic replacement. Subjects with active pericardial disease, heart failure, liver disease, renal disease, recent malignancy, haematological disorders, hypoproteinaemia, pregnancy and diabetes were excluded. At the time of surgery, the pericardial space was opened using an electric scalpel to minimise traumatic bleeding, and two separate $2 \mathrm{~mL}$ samples were obtained for analysis. Samples with evidence of haemolysis were discarded. The samples underwent biochemical analyses, automated cell count and optical microscopy.

The authors found that physiological pericardial fluid is rich in protein, albumin, LDH and nucleated cells with low levels of glucose and cholesterol. They derived normal reference values for total protein $(1.7-4.6 \mathrm{~g} / \mathrm{dL})$, pericardial fluid/serum protein ratio (0.29-0.83), LDH (141-2613 U/L), pericardial fluid/ serum LDH ratio (0.40-2.99), albumin (1.19-3.06 g/dL) and pericardium to serum albumin gradient $(0.18-2.37 \mathrm{~g} /$ dL). Normal reference intervals were also determined by optical microscopy for nucleated cells $\left(278-5608 \times 10^{6}\right.$ cells/L), mesothelial cells $(40-3790 \times$ $10^{6}$ cells/L), leucocytes $\left(19-2210 \times 10^{6}\right.$ cells/L) and lymphocytes (19-1634 × $10^{6}$ cells/L). While the study's modest sample size likely contributes to wide reference intervals, the results imply normal physiological pericardial fluid would meet traditional criteria for an exudate. The authors hypothesise that the unique composition of pericardial fluid may be due to increased pericardial vasculature permeability, pericardial mechanical stress due to cardiac contractility, or related to the abundant cell types found within the pericardial space.

The findings of the study highlight the potential for diagnostic errors when interpretive tools are used outside of their validated purpose. The Light's criteria were derived on fluid samples from a different physiological space with a composition distinct from pericardial fluid (table 1).
Table 1 Comparison of normal reference intervals of pericardial fluid to transudative pleural fluid

\begin{tabular}{|c|c|c|}
\hline & $\begin{array}{l}\text { Pericardial } \\
\text { fluid }\end{array}$ & $\begin{array}{l}\text { Pleural fluid } \\
\text { transudate }\end{array}$ \\
\hline \multicolumn{3}{|l|}{$\begin{array}{l}\text { Biochemical } \\
\text { components }\end{array}$} \\
\hline Total protein (g/dL) & $\begin{array}{l}2.8(1.7- \\
4.6)\end{array}$ & $<3.0$ \\
\hline Total protein ratio & $\begin{array}{l}0.5(0.29- \\
0.83)\end{array}$ & $\leq 0.5$ \\
\hline $\begin{array}{l}\text { Albumin gradient } \\
(\mathrm{g} / \mathrm{dL})\end{array}$ & $\begin{array}{l}1.4(0.18- \\
2.37)\end{array}$ & $\geq 1.2$ \\
\hline LDH (U/L) & $\begin{array}{l}357(141- \\
2613)\end{array}$ & $\leq 147^{*}$ \\
\hline LDH ratio & $\begin{array}{l}1.1(0.40- \\
2.99)\end{array}$ & $\leq 0.6$ \\
\hline Glucose (mg/dL) & $95(80-134)$ & $65-139+$ \\
\hline $\begin{array}{l}\text { Total cholesterol } \\
(\mathrm{mg} / \mathrm{dL})\end{array}$ & $27(12-69)$ & $\leq 45$ \\
\hline \multicolumn{3}{|l|}{ Cellular counts } \\
\hline $\begin{array}{l}\text { Leucocytes } \\
\left(10^{6} \text { cells/L) }\right.\end{array}$ & $503(35-2210)$ & $\begin{array}{l}125(83- \\
214)\end{array}$ \\
\hline $\begin{array}{l}\text { Mesothelial cells } \\
\left(10^{6} \text { cells/L) }\right.\end{array}$ & $\begin{array}{l}1283(40- \\
3790)\end{array}$ & $1(0-2)$ \\
\hline $\begin{array}{l}\text { Lymphocytes } \\
\left(10^{6} \text { cells/L) }\right.\end{array}$ & 304 (19-1634) & $23(16-31)$ \\
\hline $\begin{array}{l}\text { Polymorphonucleated } \\
\text { cells, }\left(10^{6} \text { cells/L) }\right.\end{array}$ & $2(0-116)$ & $1(0-2)$ \\
\hline $\begin{array}{l}\text { Macrophages, } \\
\left(10^{6} \text { cells/L) }\right.\end{array}$ & $1(0-207)$ & $75(64-81)$ \\
\hline
\end{tabular}

*Value is two-thirds of the upper limit of normal for those aged 18 years or older (222 IU/L).

tSimilar to blood glucose concentration.

Based on the current study, normal physiological samples would be routinely misclassified as exudates due to the rich cellularity and biochemical composition of pericardial fluid. Similar misclassification would likely occur with pathological specimens. More work remains to determine an adequate schema able to differentiate between transudative and exudative pericardial fluid. However, the efforts put forth by the authors to first define the normal composition of pericardial fluid is crucial and should be commended. This study is a step forward in the management of pericardial disease and provides a new standard in interpreting pathological pericardial fluid specimens.

Contributors EAF and CJZ: Drafting and critical revision of the manuscript.

Funding The authors have not declared a specific grant for this research from any funding agency in the public, commercial or not-for-profit sectors.

Competing interests None declared.

Patient and public involvement Patients and/or the public were not involved in the design, or conduct, or reporting, or dissemination plans of this research.

Patient consent for publication Not required. 
Provenance and peer review Commissioned; internally peer reviewed.

\section{(2) \\ OPEN ACCESS}

Open access This is an open access article distributed in accordance with the Creative Commons Attribution Non Commercial (CC BY-NC 4.0) license, which permits others to distribute, remix, adapt, build upon this work non-commercially, and license their derivative works on different terms, provided the original work is properly cited, appropriate credit is given, any changes made indicated, and the use is non-commercial. See: http://creativecommons.org/ licenses/by-nc/4.0/.

(c) Author(s) (or their employer(s)) 2021. Re-use permitted under CC BY-NC. No commercial re-use. See rights and permissions. Published by BMJ.

\section{Check for updates}

To cite Fender EA, Zack CJ. Heart 2021;107:1528-1529.

Published Online First 7 July 2021

\section{(5) Linked}

- http://dx.doi.org/10.1136/heartjnl-2020-317966

Heart 2021;107:1528-1529.

doi:10.1136/heartjnl-2021-319929

ORCID iD

Erin A Fender http://orcid.org/0000-0003-1513-0169

\section{REFERENCES}

1 Imazio M, Cecchi E, Demichelis B, et al. Myopericarditis versus viral or idiopathic acute pericarditis. Heart 2008:94:498-501.
2 Gad MM, Elgendy IY, Mahmoud AN, et al. Temporal trends, outcomes, and predictors of mortality after pericardiocentesis in the United States. Catheter Cardiovasc Interv 2020;95:375-86.

3 Adler Y, The CP. ESC guidelines on the diagnosis and management of pericardial diseases. Eur Heart J 2015:2015:2873-4.

4 Light RW, Macgregor MI, Luchsinger PC, et al. Pleural effusions: the diagnostic separation of transudates and exudates. Ann Intern Med 1972;77:507-13.

5 Ben-Horin S, Shinfeld A, Kachel E, et al. The composition of normal pericardial fluid and its implications for diagnosing pericardial effusions. Am J Med 2005;118:636-40.

6 Imazio M, Biondo A, Ricci D, et al. Contemporary biochemical analysis of normal pericardial fluid. Heart 2020;106:541-4

7 Buoro S, Tombetti E, Ceriotti F. What is the normal composition of pericardial fluid? Heart 2021;107:1584-90. 